\title{
Docosahexaenoic acid ethyl esther (DHAEE) microcapsule production by spray-drying: optimization by experimental design
}

\author{
Obtenção de microcápsulas do éster etílico do ácido docosa-hexaenoico (DHAEE) \\ por atomização: otimização através de planejamento experimental
}

\section{Rodney Alexandre Ferreira RODRIGUES ${ }^{1 \star}$, Marili Villa Nova RODRIGUES ${ }^{1}$, Thais Isabel Vaccaro OLIVEIRA ${ }^{1}$, Cecilia Zorzi BUENO ${ }^{1}$, Ilza Maria de Oliveira SOUZA ${ }^{1}$, Adilson SARTORATTO' ${ }^{1}$, Mary Ann FOGLIO ${ }^{1}$}

\begin{abstract}
Docosahexaenoic acid is an essential polyunsaturated fatty acid with important metabolic activities. Its conjugated double bonds make it susceptible to decomposition. Its stability may be improved through fatty acid entrapment with a spray-drying technique; however, the many parameters involved in this technique must be considered to avoid affecting the final product quality. Therefore, this study aimed to evaluate the entrapment conditions and yields of fish oil enriched with docosahexaenoic acid ethyl ester. Microcapsules were obtained from Acacia gum using a spray-drying technique. The experimental samples were analyzed by chromatography and delineated by Statistica software, which found the following optimum entrapment conditions: an inlet temperature of $188{ }^{\circ} \mathrm{C} ; 30 \%$ core material; an $\mathrm{N}_{2}$ flow rate of 55 mm; and a pump flow rate of $12.5 \mathrm{~mL} /$ minute. These conditions provided a $66 \%$ yield of docosahexaenoic acid ethyl ester in the oil, corresponding to $19.8 \%$ of entrapped docosahexaenoic acid ethyl ester (w/w). This result was considered significant since $30 \%$ corresponded to wall material. Keywords: encapsulated fish oil; gas chromatography; response surface; optimized conditions; omega-3.
\end{abstract}

\section{Resumo}

O ácido docoso-hexaenoico é um ácido graxo poli-insaturado essencial que desempenha importantes ações metabólicas. Entretanto, por possuir duplas ligações conjugadas torna-se suscetível à decomposição. Uma das formas de minimizar esta possível decomposição é o emprego da técnica de atomização para microencapsulação. Porém, esta técnica envolve uma série de parâmetros de processo, que podem vir a alterar a qualidade do produto final. Assim, o objetivo deste trabalho foi microencapsular óleo de peixe enriquecido no éster etílico do ácido docoso-hexaenoico (DHAEE-85\%), variando condições operacionais e avaliar o rendimento pela análise por cromatografia gasosa, após extração das microcápsulas. Para tanto, foi utilizado o processo de microencapsulação por atomização e o agente encapsulante foi a goma arábica. A avaliação cromatográfica de vários experimentos delineados pelo software Statistica, mostrou que os pontos ótimos para obtenção das microcápsulas de DHAEE foram: temperatura de entrada $188^{\circ} \mathrm{C}$, porcentagem de recheio $30 \%$, vazão de nitrogênio 55 mm $\mathrm{N}_{2}$ e vazão da bomba de $12,5 \mathrm{~mL} /$ minuto. Estas condições de processo foram testadas experimentalmente, resultando no teor de $66 \% \mathrm{~m} / \mathrm{m}$ de DHAEE no óleo extraído, valor correspondente a $19,8 \% \mathrm{~m} / \mathrm{m}$ de DHAEE encapsulado, valor considerado satisfatório uma vez que $30 \%$ das microcápsulas correspondiam teoricamente ao material de parede.

Palavras-chave: óleo de peixe encapsulado; cromatografia gasosa; superfície de resposta; condições otimizadas; ômega-3.

\section{Introduction}

In recent decades, several studies have focused on the health benefits of foods containing PUFAs (polyunsaturated fatty acids), particularly their association with a decreased incidence of coronary heart disease.

PUFAs are polyunsaturated, meaning that they contain two or more conjugated double bonds between carbon atoms (unsaturations). They are considered essential because they are not synthesized in the human body. In human beings, fatty acids play an important role in many metabolic activities and a crucial role in brain function, nerve impulse transmission, oxygen transfer in blood serum, hemoglobin synthesis, and cell division. PUFAs can be found in fish, algae, and vegetable oil (MARTIN et al., 2006). Seventy percent of the world's edible oils comes from vegetables, whereas only two percent is of animal origin (NARAYAN; MIYASHITA; HOSAKAWA, 2006). In some cases, PUFAs are used as additives, for example, in milk, yogurt, bread, pasta, eggs, and animal feed (MARTIN et al., 2006). Certain cereals and legumes such as oats, rice, beans, and peas may contain fatty acids (MARTIN et al., 2006). Dark, leafy green vegetables contain many more chloroplasts and therefore contain a greater amount of fatty acids. A vegetarian diet, for example, must include watercress, kale, lettuce, spinach, and broccoli to ensure an adequate PUFA intake (SIMOPOULOS, 2002).

Some PUFAS are important for human health. These include docosahexaenoic acid (DHA) and eicosapentaenoic acid (EPA), which are omega-3 fatty acids and alpha-linolenic acid (ALA), which can be metabolized and transformed by the body into

Received $1 / 4 / 2009$

Accepted 9/7/2010 (004140)

${ }^{1}$ Centro Pluridisciplinar de Pesquisas, Químicas, Biológicas e Agrícolas, Universidade Estadual de Campinas - UNICAMP, Rua Alexandre Cazelatto, n. 999,

CEP 13140-000, Vila Betel, Paulinia, SP, Brasil,e-mail: rodney@cpqba.unicamp.br

${ }^{*}$ Corresponding author 
EPA and DHA (SEATON, 2006). In freshwater fish oil, EPA and DHA can reach concentrations of 20 and $18 \mathrm{mg} \cdot \mathrm{g}^{-1}$, respectively (INHAMUNS; FRANCO, 2008). Fatty acids can be described by their molecule size; fatty acids with at least 16 carbon atoms are considered long-chain fatty acids, whereas those with more than 20 atoms are considered very-long-chain fatty acids. They can also be classified as either omega- 3 or omega- 6 fatty acids (MARTIN et al., 2006). These acids are known to play important roles in human health, and they are involved in fundamental life stages, including gestation (KRABBENDAM et al., 2007), the first months of life, and aging. They have a positive impact upon diseases such as diabetes, cancer, thrombosis, asthma, hypertension, heart disease, rheumatoid arthritis, Crohn's disease and others (SHAHIDI; WANASUNDARA, 1998; UAUY; VALENZUELA, 2000; LAMPRECHT; SCHÄFER; LEHR, 2001).

DHA stands out from other PUFAs due to its great applicability in medication formulations; its molecular structure is illustrated in Figure 1.

Pharmaceutical formulations containing PUFAs may vary in composition and type. Microcapsules may be used to avoid transferring fatty acids from inside to outside or to avoid degradation caused by adverse conditions such as light, oxygen, humidity, and reactive ingredients. In addition, microencapsulation aims to prevent agglomerates and improve manipulability by reducing hygroscopicity and increasing uniformity, transforming liquids into solids for use in dry systems, controlling liberation velocity, and masking tastes and smells (RÉ, 1998; SHAHIDI; HAN, 1993).

Among the different methods of microencapsulation, atomization, or spray-drying, is the most commonly used technique in the food industry. Spray-drying equipment is relatively easy to operate, operates quickly, and produces high quality, uniform, spherical particles. It allows continuous processing, processing of large volumes, and processing at atmospheric pressure, and it results in high yields. Taken together, these qualities allow for the inexpensive commercialization of products despite the expensive equipment spray-drying requires (WENDEL; CELIK, 1998; FILKOVÁ; MUJUMDAR, 1995).

Many variables associated with the spray-drying process, including inlet and outlet air temperature, drag gas flow rate, temperature, and humidity distribution, permanence time, and chamber geometry can affect properties of the resulting products. Therefore, these variables must be studied and adjusted to achieve good productivity and reproducibility (AHN et al., 2008). In addition to the inherent properties of the process, the inherent properties of the product must also be taken into account. Such properties include density, apparent volume, particle size distribution, humidity, agglomeration, and stability, among others (LEITE, 2001).

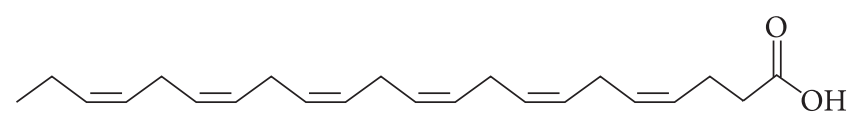

Figure 1. Molecular structure of docosahexaenoic acid (DHA).
Contrary to the common belief about high-temperature spray-drying technique, the rapid evaporation associated with this method maintains a low droplet temperature that does not affect the final product. This makes spray-drying appropriate for heat-sensitive products and biological and pharmaceutical products (RÉ, 2000; FILKOVÁ; MUJUMBAR, 1995).

Spray-drying is based on selective diffusion, in which a reduction in the diffusion coefficient of water and the sample constituents takes place during the drying process. As a result of the difference between the molecular masses, this reduction is greater for volatile substances. When a film begins to form, the diffusibility of the volatile substances becomes so low that the solid matrix becomes entrapped. At this point, water can still diffuse through the membrane, which becomes a selective filter. This explains why volatile substances are lost primarily during the first stages of drying, whereas water loss occurs at a constant rate throughout the process.

The first step of the entrapment process is selecting an appropriate polymer. It must have emulsifying properties, filmforming capacities, low viscosity (even in solutions with a high solids content), stability, low hygroscopicity, low cost and no taste, and it must adequately protect the encapsulated ingredient (SHAHIDI; HAN, 1993).

The choice of the polymer depends on the physical and chemical properties of the material to be encapsulated, the process used to form the microcapsules, and the pharmacodynamic goals (NORI, 1996). Factors that can alter content retention during entrapment include molecular mass, structural conformation, chemical function, physical state, and the thickness and surface area of the microcapsule (GOUBET; QUERE; VOILLEY, 1998). Gums, carbohydrates, cellulose and its derivates, lipids, and proteins can be used as entrapment agents (SHAHIDI; HAN, 1993). The high demand from the international market greatly encourages the use of gums from exudates and plant extracts (BOTELHO, 1999). Acacia gum, also known as gum arabic, is the best known exudate gum. Eighty percent of gum arabic originates from Acacia senegal (Fabaceae), and 10 to 15\% from A. seyal, found in Senegal, Mali, Mauritania, Nigeria, Chad, and Sudan (BUFFO; REINECCIUS; OEHLERT, 2001; ROBBERS; SPEEDIE; TYLER, 1997; WAREING, 1997). This exudate is a polysaccharide mainly composed of galactose (61\%) and other sugars, including arabinose, rhamnose, glucose and glucuronic acid. It is odorless, tasteless, water soluble, slightly acidic, nontoxic, and contains little color (CHATTOPADHYAYA; SINGHAL; KULKARN, 1998; WAREING, 1997; ZAKARIA; RAHMAN, 1996). Acacia gum is considered one of the food industry's best materials for manufacturing microcapsules due to its capacity for promoting emulsification, stabilization, and antioxidation, as well as its very low viscosity compared with other gums. Its viscosity tends to increase at concentrations above $30 \%$; however, its viscosity is still sufficiently low to permit solutions at concentrations of 55\%, a concentration ten times higher than other gums' limit of approximately 5\% (BUFFO; REINECCIUS; OEHLERT, 2001; WAREING, 1997; DE PAULA; RODRIGUES, 1995; DZIEZAK, 1991).

This study aimed to standardize and optimize the experimental conditions of DHA ethyl ester (DHAEE) microcapsule production using the spray-drying technique. 
A central composite experimental design was generated using the following variables: DHAEE percentages (15 to 35\%), inlet temperature (155 to $215{ }^{\circ} \mathrm{C}$ ), atomizer gas flow rate (from 52 to $60 \mathrm{~mm}$ of $\mathrm{N}_{2}, 635$ to $730 \mathrm{~L} / \mathrm{h}$ ), and pump flow rate (from 7.5 to $17.5 \mathrm{~mL} / \mathrm{minute}, 25$ to $58 \%$ ). The DHAEE content of the microcapsules was the efficiency measurement.

\section{Materials and methods}

Microcapsules were obtained using fish oil with $85 \%$ DHAEE (GC-FID) donated by K.D. Pharma, Bexbach, Germany, and pure powdered gum arabic and Tween 80 (USP grade) acquired at Synth, Brazil.

The solvents used were absolute ethanol, all analytical grade, and acquired from Ecibra, Brazil; dibutylphthalate manufactured by Mallinckrodt, USA; and acetone manufactured by Merck, Brazil.

The equipment used included a mini spray-dryer model B-290 with inert loop B-295, manufactured by Büchi, Flawil, Switzerland; an Ultra-turrax T10 basic disperser, manufactured by Ika, Staufen, Germany; a test tube agitator, model AP56, manufactured by Phoenix, Araraquara, Brazil; gas chromatograph, model 6890, manufactured by HP, Palo Alto, CA, USA, interfaced with an HP 5975 mass selective detector and HP 7673 automatic injector; an ultrasonic bath, model B-220, manufactured by Bransonic 220, São Paulo, Brazil, and a rotaevaporator, model R-205, manufactured by Büchi, Flawil, Switzerland.

\subsection{Experimental design}

We designed a $2^{4}$ central composite experiment using DHAEE percentages ranging from 15 to $35 \%$ and such equipment parameters as inlet temperature (ranging from 155 to $215^{\circ} \mathrm{C}$ ), atomizer gas flow rate (ranging from 52 to $60 \mathrm{~mm}$ of $\mathrm{N}_{2}, 635$ to $730 \mathrm{~L} / \mathrm{h}$ ), and pump flow rate (ranging from 25 to $58 \%, 7.5$ to $17.5 \mathrm{~mL} / \mathrm{minute}$ ) as the variables. The response was determined by entrapment efficiency, which was calculated as the percentage of DHAEE contained in the microcapsules.

\subsection{Preparation of microcapsules}

The total sum of the DHAEE mass, gum, and Tween 80 (emulsifier) was established at $9.0 \mathrm{~g}$ for all design trials, regardless of the amount of gum used.

In a $50 \mathrm{~mL}$ plastic tube, an emulsion of gum arabic was prepared with $20 \mathrm{~mL}$ of water. The tube was agitated for 20 seconds; next it was immersed in an ultrasonic bath. The predetermined quantity of DHAEE for that trial was then added, along with $0.9 \mathrm{~mL}$ of Tween 80 . The tube was returned to the test tube agitator for another 20 seconds and then placed in the disperser for another 3 minutes.

Figure 2 shows the proportions of DHAEE, gum Arabic, and emulsifier used in the experimental design trials.

The emulsions obtained were submitted to spray-drying. The values for the atomizer nozzle-cleaning device $\left(n^{\circ} 4\right)$ and nitrogen pump (90\%) were kept constant for all trials. The other parameters were adjusted according to the experimental design and are described in Table 1.

Before and after the samples were processed by spraydrying, the atomizer was pumped with water for a few minutes to ensure that it was clean and that the nozzle was free of any clogging.

The microcapsules obtained were collected and analytically weighed to calculate the process yield.

\subsection{Analytical instrumentation}

Chromatographic analyses were conducted with an Agilent $6890 \mathrm{~N}$ gas chromatograph interfaced with a 5975 selective mass detector and a 7683B automatic injector. The chromatographic separation was performed using $30 \mathrm{~m}$ J\&W Scientific HP-5 MS 5\%-(phenyl)-methylpolysiloxane capillary columns with a $0.25 \mathrm{~mm}$ internal diameter and $0.25 \mu \mathrm{m}$ film thickness. Injections were automatic $(1 \mu \mathrm{L})$, with a $1 / 50$ split ratio. The gas (helium) flow drag was $1 \mathrm{~mL} /$ minute.

The optimization of the chromatographic conditions for the separation of DHAEE and dibutyl phthalate from the sample constituents in GC-MS were carried out in SCAN mode defined by the following condition: the initial column temperature was $50{ }^{\circ} \mathrm{C} / 1 \mathrm{~min}$. It was warmed at $4{ }^{\circ} \mathrm{C} /$ minute to $110{ }^{\circ} \mathrm{C}$, then at $20{ }^{\circ} \mathrm{C} /$ minute to $220^{\circ} \mathrm{C}$ and maintained at this temperature for 23.5 minutes. The injector temperature was $220^{\circ} \mathrm{C}$ with an interface of $250^{\circ} \mathrm{C}$ with a 3 minutes delay.

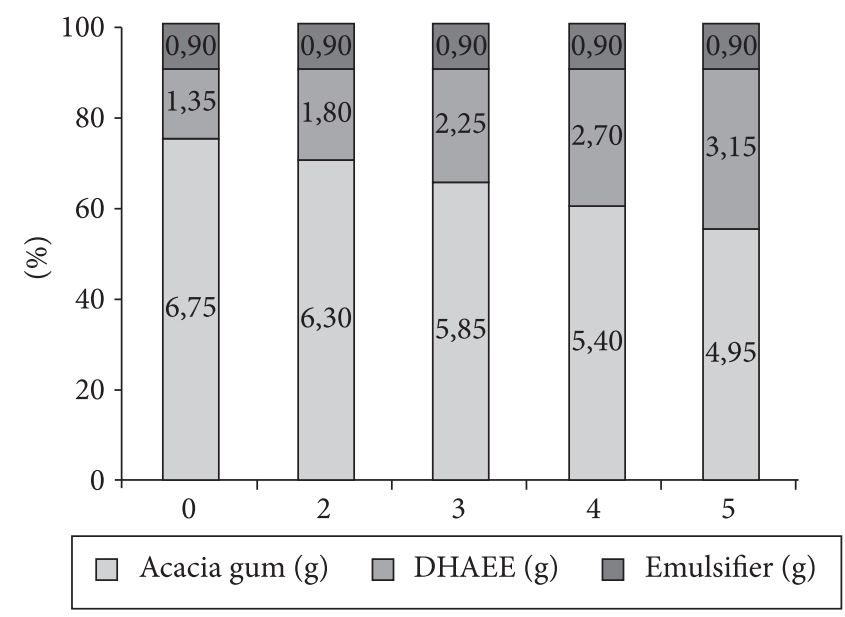

Figure 2. Proportions of gum arabic, DHAEE, and emulsifier used in the preparation of the microcapsules.

Table 1. Mass selective detector (SIM mode) analyses of microcapsules containing DHAEE.

\begin{tabular}{lcc}
\hline \multicolumn{1}{c}{ Compound } & $\begin{array}{c}\text { Quantification ions } \\
(\mathrm{QI})\end{array}$ & $\begin{array}{c}\text { Identification ions } \\
(\mathrm{II})\end{array}$ \\
\hline DHAEE & 79 & $55,91,131$ \\
Dibutylphthalate $^{*}$ & 149 & $104,150,223$ \\
\hline
\end{tabular}


The mass selective detector was used in single ion monitoring (SIM) mode, which allows enhanced detection for quantification. For DHAEE and the internal standard, the most abundant fragments were designated quantification ions (QI), and another two ions were designated identification ions (II), based on the elution time of each analyte. Retention time and the relative abundance of QI and II were used as confirmation criteria.

Table 1 shows the ions used to quantify the amount of DHAEE in the microcapsules, as determined by the mass detector program operating in SIM mode.

\subsection{Analytical curve}

DHAEE quantification was conducted using the internal standardization method. An analytical curve with 6 concentration points ranging from 50 to $250 \mu \mathrm{g} \cdot \mathrm{mL}^{-1}$ was conducted starting with the dilution for a $10 \mathrm{~mL}$ volumetric flask of different aliquots of the DHAEE stock solution containing $500 \mu \mathrm{g} \cdot \mathrm{mL}^{-1}$ acetone and adding $1.0 \mathrm{~mL}$ of dibutylphthalate solution at $20 \mu \mathrm{g} \cdot \mathrm{mL}^{-1}$.

\subsection{Microcapsule extraction for GC-MS analysis}

The extraction of the DHAEE contained in the microcapsules was performed in duplicate. For each experimental sample, one and a half grams was extracted with $3 \mathrm{~mL}$ of ethanol and $45 \mathrm{~mL}$ of hexane in an Ultra-Turrax disperser for 4 minutes at $6500 \mathrm{rpm}$. The extracted material was vacuum filtered, successively washed with $15 \mathrm{~mL}$ hexane and $20 \mathrm{~mL}$ ethanol, and concentrated in a rotaevaporator with a $40{ }^{\circ} \mathrm{C}$ bath until the solvents were eliminated. The oily residue was diluted with acetone and $1 \mathrm{~mL}$ of the internal standard and analyzed by GC-MS DHAEE quantification.

\subsection{Statistical analysis}

Statistical calculus was conducted using the Statistic (StatSoft, Inc., EUA) v. 5.5 program.

\section{Results and discussion}

The DHAEE content in the microcapsules was calculated according to Equation 1 below, and the results were used to construct the response surfaces (Table 2). Figure 3 presents the chromatogram obtained in the condition for the central point (Trial 25).

DHAEE content in the microcapsules $=$

DHAEE content in the core material $\times$ core-material percentage

Quantification using the internal standardization method was simple and effective in avoiding possible losses during

Table 2. DHAEE content in the core material (extracted oil) and microcapsules, according to the variations of the experimental design.

\begin{tabular}{|c|c|c|c|c|c|c|}
\hline & $\begin{array}{c}\mathrm{T} \\
\left({ }^{\circ} \mathrm{C}\right)\end{array}$ & $\begin{array}{c}\text { Theoretical \% of } \\
\text { core material }\end{array}$ & $\begin{array}{l}\text { Atomizer flow rate } \\
\left(\mathrm{mm} \mathrm{N}_{2}\right)\end{array}$ & $\begin{array}{c}\text { Pump flow rate } \\
(\mathrm{mL} / \mathrm{minute})\end{array}$ & $\begin{array}{c}\text { DHAEE in core } \\
\text { material }(\% \mathrm{~m} / \mathrm{m})\end{array}$ & $\begin{array}{c}\text { DHAEE in microcapsule } \\
(\% \mathrm{~m} / \mathrm{m})\end{array}$ \\
\hline 1 & 170 & 20 & 54 & 10 & 39.34 & 7.86 \\
\hline 2 & 170 & 20 & 54 & 15 & 38.69 & 8.15 \\
\hline 3 & 170 & 20 & 58 & 10 & 44.59 & 9.21 \\
\hline 4 & 170 & 20 & 58 & 15 & 47.17 & 9.95 \\
\hline 5 & 170 & 30 & 54 & 10 & 35.72 & 10.66 \\
\hline 8 & 170 & 30 & 58 & 15 & 43.54 & 13.15 \\
\hline 9 & 200 & 20 & 54 & 10 & 36.86 & 7.88 \\
\hline 10 & 200 & 20 & 54 & 15 & 33.04 & 6.73 \\
\hline 11 & 200 & 20 & 58 & 10 & 44.78 & 9.85 \\
\hline 12 & 200 & 20 & 58 & 15 & 38.32 & 7.65 \\
\hline 16 & 200 & 30 & 58 & 15 & 43.02 & 13.11 \\
\hline 17 & 155 & 25 & 56 & 12.5 & 35.33 & 8.85 \\
\hline 18 & 215 & 25 & 56 & 12.5 & 21.72 & 5.46 \\
\hline 19 & 185 & 15 & 56 & 12.5 & 28.29 & 4.73 \\
\hline 20 & 185 & 35 & 56 & 12.5 & 50.06 & 17.52 \\
\hline 21 & 185 & 25 & 52 & 12.5 & 54.71 & 14.06 \\
\hline 22 & 185 & 25 & 60 & 12.5 & 55.50 & 14.07 \\
\hline 23 & 185 & 25 & 56 & 7.5 & 27.16 & 6.86 \\
\hline 24 & 185 & 25 & 56 & 17.5 & 27.29 & 7.03 \\
\hline 25 & 185 & 25 & 56 & 12.5 & 54.37 & 13.80 \\
\hline 26 & 185 & 25 & 56 & 12.5 & 52.49 & 13.26 \\
\hline
\end{tabular}


chromatograph injection, and the mass detector in SIM mode provided chromatograms with no interference (Figure 3) due to its high selectivity.

The results obtained during the various trials (Table 2) were analyzed with the Statistic program. The variance analysis (ANOVA) presented in Table 3 indicates that the model was adequate, explaining $94.7 \%$ of the variations.

The variance analysis demonstrated that the model used fit the experimental data well, and that regression was statistically significant at a $95 \%$ confidence level.

Table 4 presents the effects of the variables studied in the response.

Table 4 shows that the inlet temperature of the equipment had a $-3.39 \%$ effect on the DHAEE content in the microcapsules demonstrating that temperature increases (from 155 to $215^{\circ} \mathrm{C}$ ) led to losses, probably because of ester volatilization once it was undetected degradation compounds by GC-MS. Cappi, De Jesus and Maciel Filho (2001) examined the use of spray-drying with $\alpha$-amylase and noticed a similar response to temperature increases. These results also agree with those of De Jesus (2002), who compared the effects of atomization, freeze-drying, and microwaving on $a$-amylase.
Varying the core material from 20 to $30 \%$ produced positive effects, and increasing it from 15 to $35 \%$ had a negative effect. Hence, core-material concentrations can be limiting up to a certain point making entrapment above these values difficult.

Table 4. Effects of variables upon DHAEE content in microcapsules.

\begin{tabular}{|c|c|}
\hline Variables & Effects \\
\hline Temperature (L) & 0.14 \\
\hline Temperature (Q) & $-3.39^{*}$ \\
\hline$\%$ core material $(\mathrm{L})$ & $3.84^{*}$ \\
\hline$\%$ core material $(\mathrm{Q})$ & $-1.82^{*}$ \\
\hline Atomizer gas flow rate: $\mathrm{mm} \mathrm{N}_{2}(\mathrm{~L})$ & 0.55 \\
\hline Atomizer gas flow rate: $\mathrm{mm} \mathrm{N}_{2}(\mathrm{Q})$ & 0.48 \\
\hline Pump flow rate: $\%(\mathrm{~L})$ & -0.28 \\
\hline Pump flow rate: \% (Q) & $-3.08^{*}$ \\
\hline Temperature $(\mathrm{L}) \times \%$ core material $(\mathrm{L})$ & 0.58 \\
\hline Temperature $(\mathrm{L}) \times$ atomizer gas flow rate: $\mathrm{mm} \mathrm{N}_{2}(\mathrm{~L})$ & $-1.15^{\star}$ \\
\hline Temperature $(\mathrm{L}) \times$ pump flow rate: $\%(\mathrm{~L})$ & -0.39 \\
\hline$\%$ core material $(\mathrm{L}) \times$ atomizer gas flow rate: $\mathrm{mm} \mathrm{N}_{2}(\mathrm{~L})$ & 0.26 \\
\hline$\%$ core material $(\mathrm{L}) \times$ pump flow rate: $\%(\mathrm{~L})$ & 0.08 \\
\hline Atomizer gas flow rate: $\mathrm{mm} \mathrm{N}_{2}(\mathrm{~L}) \times$ pump flow rate: $\%$ (L) & -0.26 \\
\hline
\end{tabular}

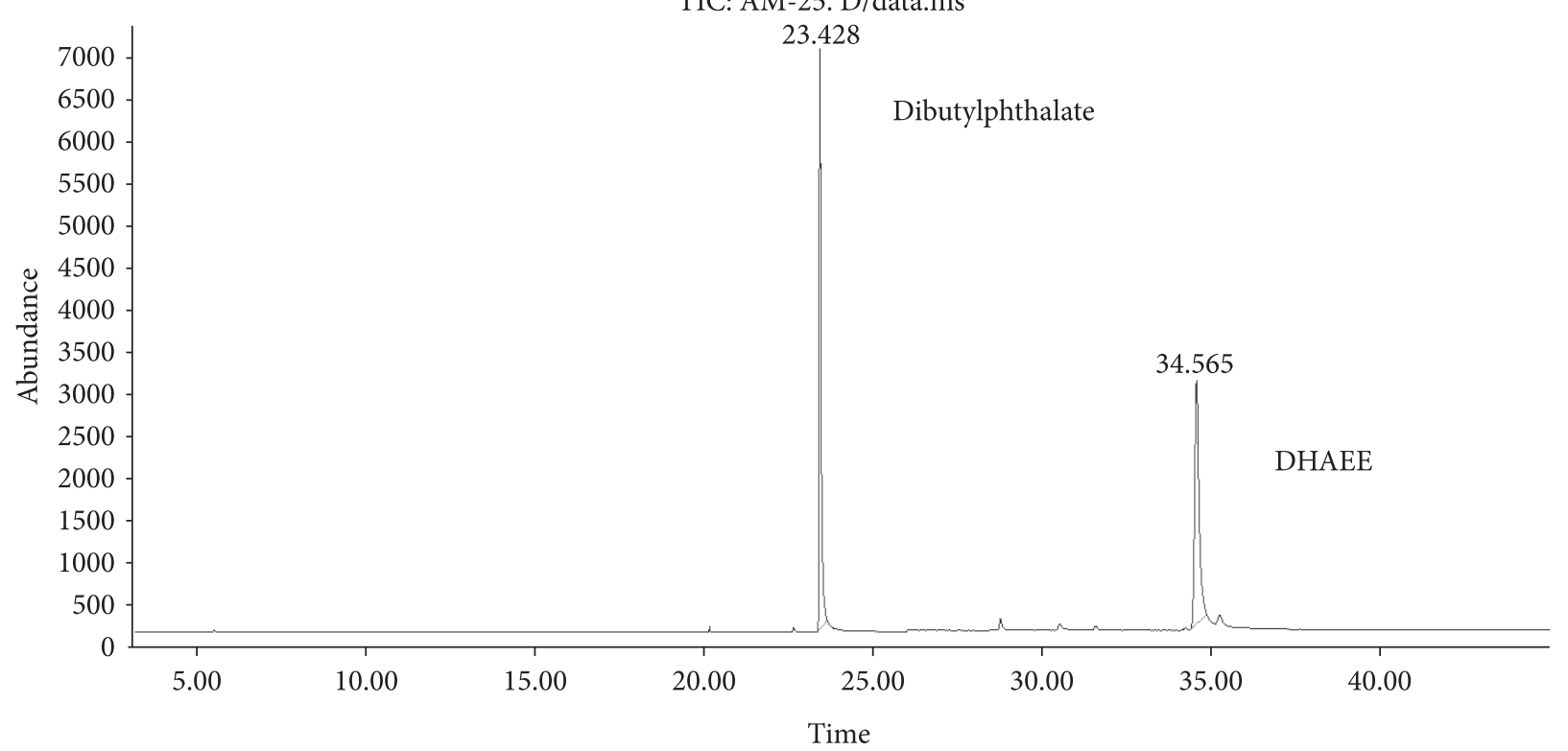

Figure 3. Chromatogram from the GC-MS (SIM) of the microcapsules obtained from the experimental conditions of the central point of the design.

Table 3. Variance analysis (ANOVA) for the adjustment of the quadratic model.

\begin{tabular}{lcccc}
\hline \multicolumn{1}{c}{ Variation source } & Quadratic sum & Degrees of freedom & Quadratic mean & F-test \\
\hline Regression & 210.4959 & 14 & 15.0354 & 12.02 \\
Residues & 15.0085 & 12 & 1.2507 & $0.74^{*}$ \\
Lack of adjustment & 9.4560 & 10 & 0.9456 & 1.2763 \\
Pure error & 2.5525 & 2 & & \\
\hline
\end{tabular}

$\left.{ }^{*}\right)$ Non significant; R2 $=0.9468$. 
(a)

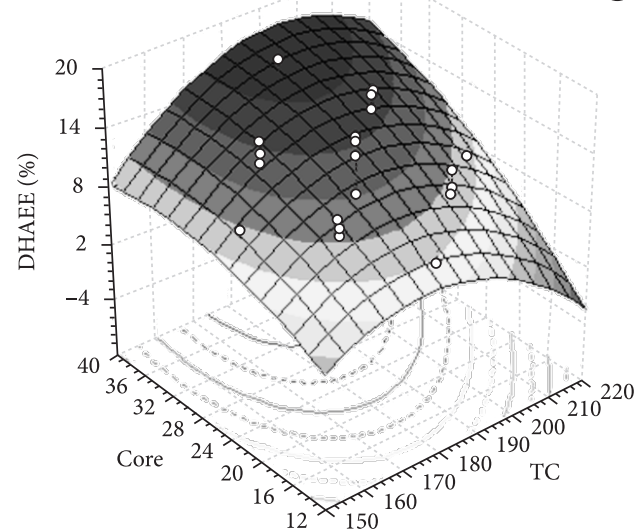

\begin{tabular}{|c|c|c|c|c|c|}
\hline$\square-4.594$ & $\square-2.407$ & $\square-0.220$ & $\square 1.967$ & $\square 4.155$ & $\square 6.342$ \\
\hline$\square 8.529$ & $\square 10.716$ & $\square 12.903$ & 口 15.090 & $\square$ Above & \\
\hline
\end{tabular}

(c)

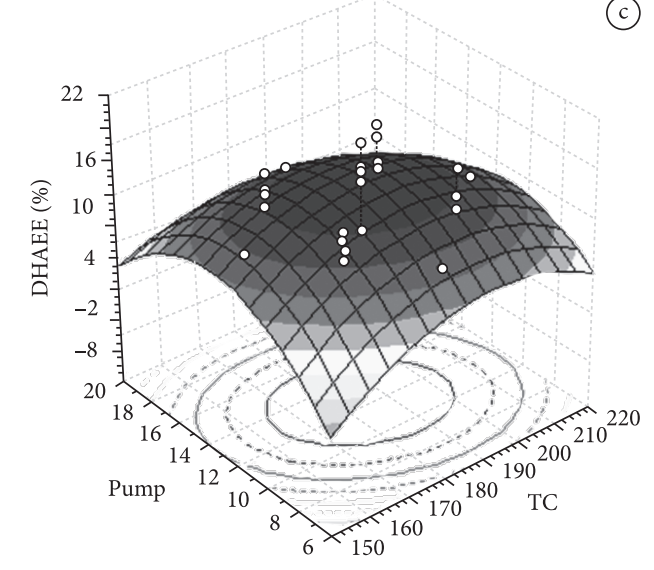

\begin{tabular}{|lllllll|}
\hline$\square-9.447$ & $\square-7.215$ & $\square-4.983$ & $\square-2.751$ & $\square-0.519$ & $\square 1.713$ \\
$\square 3.945$ & $\square 6.177$ & $\square 8.408$ & $\square$ & 10.640 & $\square$ Above & \\
\hline
\end{tabular}

(e)

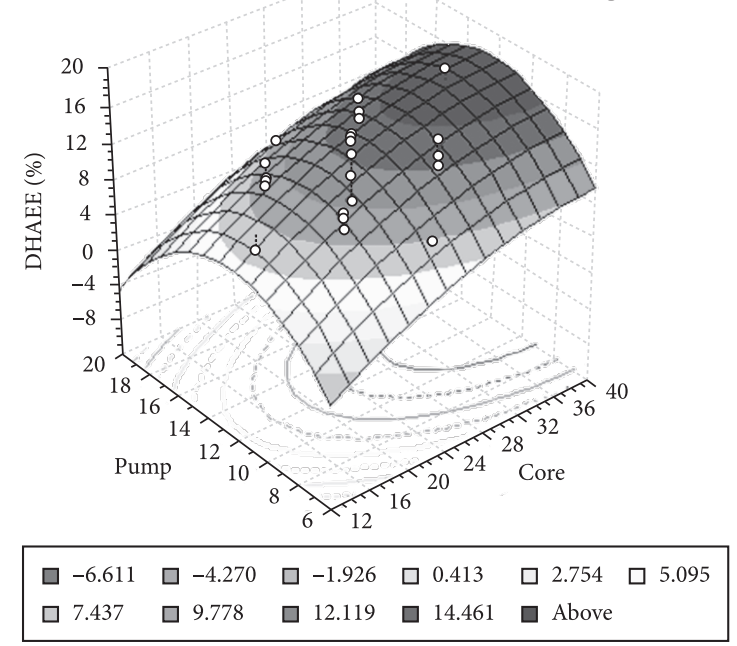

(b)

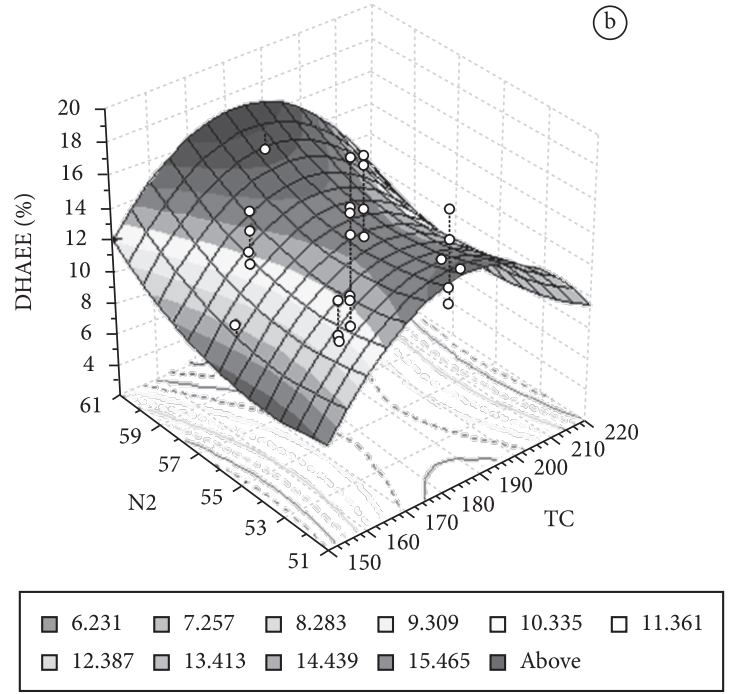

(d)

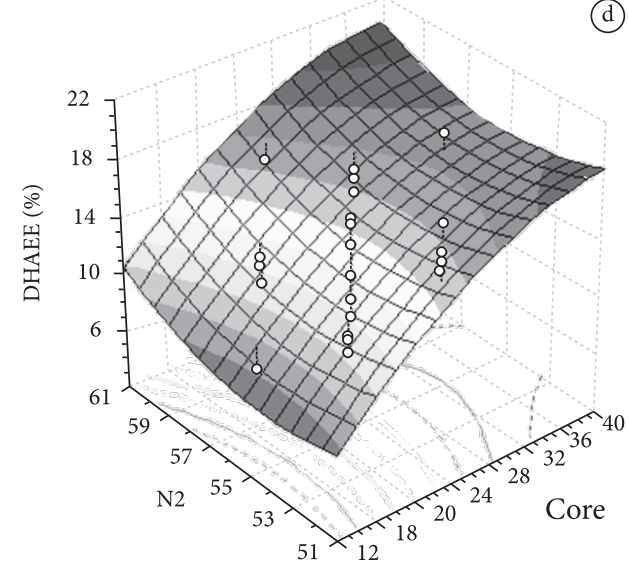

$\square 5.560 \quad \square 7.005 \quad \square 8.449 \quad \square 9.894 \quad \square 11.339 \quad \square 12.784$

$\square 14.229 \square 15.674 \quad \square \quad 17.118 \quad \square 10.563 \quad \square$ Above

(f)

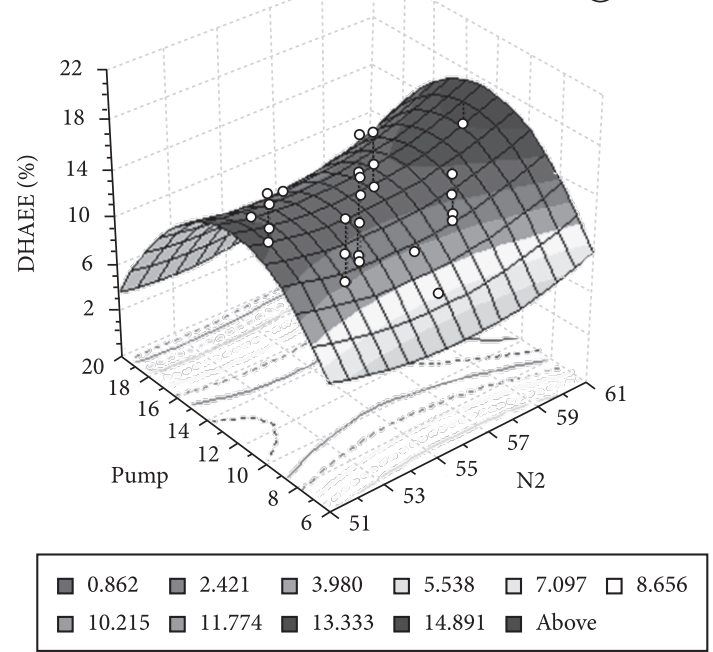

Figure 4. Response surfaces obtained by adjusting the quadratic model of the experimental data from Table 4 , where a) temperature $\times$ core material; b) temperature $\times$ atomizer gas flow rate; $c$ ) temperature $\times$ pump flow rate; $d$ ) core material $\times$ atomizer gas flow rate; and e) core material $\times$ pump flow rate; $f$ ) pump flow rate $\times$ atomizer gas flow rate. 
Bertolini, Siani and Grosso (2001), in a study of monoterpene entrapment with gum arabic using spray-drying, observed that the best yields occurred with core-material concentrations of $10 \%$, in the studied range of 10 to $30 \%$. Pauletti and Amestoy (1999) evaluated butter entrapment in maltodextrin using atomization and also observed that core-material percentage increases reduced the final yield of the process.

An increase in percentage is sometimes beneficial, as observed by Rodrigues (2004), whose study of coffee microcapsule extraction with cryoconcentration found that yields increased when the core material was increased from 20 to $30 \%$. Therefore, we posit that the relationship between yield and core-material percentage is related to several factors inherent to the core material's chemical nature including its molecular mass, chemical functionality, relative volatility, and polarity, as demonstrated by Chang, Scire and Jacobs (1988).

The pump flow rate also led to a $3.08 \%$ loss of encapsulated DHAEE when it increased from 7.5 to $17.5 \mathrm{~mL} /$ minute. Elevated flow rates impaired the encapsulation process. According to Ré (1998), drop-drying is a complicated method, due to the wide range of drop size distribution and the complex ratio of atomized drop to air. In addition, during the drying process, the drop contains a concentration gradient of water; eventually, the surface activity of this water will decrease and the surface will dry. This triggers a period of decreased drying rate, when the movement of moisture inside the drops will become a limiting factor. Therefore, we can conclude that the pump flow rate can impair the encapsulation process to a certain extent and should be evaluated on a case-by-case basis.

Of the variables studied, only the atomizer gas flow rate had no significant effect on response. There was, however, an interaction between this variable and temperature that negatively affected the response.

Figure 4 presents the response surface generated by the experimental data. The white dots represent the trials carried out.

As shown in Figure 4, the trials performed covered a significant range of the surface to reach the optimized region.

The mathematical model is presented in Equation 2 below:

$$
\begin{aligned}
& \mathrm{y}=-328.1+3.837 \mathrm{x}_{1}-0.007538 \mathrm{x}_{1}^{2}+ \\
& 0.7449 \mathrm{x}_{2}-0.03639 \mathrm{x}_{2}^{2}-3.024 \mathrm{x}_{3}+ \\
& 0.06001 \mathrm{x}_{3}^{2}+8.431 \mathrm{x}_{4}-0.2465 \\
& \mathrm{x}_{1}: \text { temperature }\left({ }^{\circ} \mathrm{C}\right) ; \\
& \mathrm{x}_{2}: \text { core-material percentage; } \\
& \mathrm{x}_{3}: \text { nitrogen flow rate }\left(\mathrm{mm}_{2}\right) ; \\
& \mathrm{x}_{4}: \text { peristaltic pump flow rate }(\mathrm{mL} / \text { minute }) \text {; and } \\
& \mathrm{y}: \text { estimated value of DHAEE }(\%) .
\end{aligned}
$$

The results of the mathematical equation indicated the optimum conditions for DHAEE entrapment: an inlet temperature of $188{ }^{\circ} \mathrm{C}$; a core-material percentage of $30 \%$; a nitrogen flow rate of $55 \mathrm{~mm} \mathrm{~N}_{2}$; and a pump flow rate of $42 \%$, which corresponds to $12.5 \mathrm{~mL} /$ minute. Theses processing conditions were tested and resulted in a $66 \% \mathrm{~m} / \mathrm{m}$ of DHAEE content in the extracted oil corresponding to $19.8 \% \mathrm{~m} / \mathrm{m}$ of entrapped DHAEE. This is a satisfactory value given that $30 \%$ of the microcapsules corresponded to core material.

\section{Conclusions}

The variables that most influenced the process for obtaining DHAEE microcapsules were the core-material percentage, temperature, and pump flow rate.

The experimental design established the optimum conditions for DHAEE entrapment, which were then confirmed experimentally.

The approach presented herein could provide useful guidelines for optimizing similar encapsulating systems.

\section{Acknowledgements}

The authors are grateful for the financial support provided by FAPESP and FINEP and to K.D. Pharma, Bexbach-Germany, for donating the DHAEE.

\section{References}

AHN, J. H. et al. Optimization of microencapsulation of seed oil by response surface methodology. Food Chemistry, v. 107, p. 98-105, 2008. http://dx.doi.org/10.1016/j.foodchem.2007.07.067

BERTOLINI, A. C.; SIANI, A. C.; GROSSO, C. R. F. Stability of monoterpenes of encapsulated in gum arabic by spray drying. Journal of Agricultural and Food Chemistry, v. 49, n. 2, p. 780-785, 2001. PMid:11262028. http://dx.doi.org/10.1021/jf000436y

BOTELHO, M. L. R. Propriedades Físico- Químicas do Exsudato de Anacardium occidentale L para Indústria de Alimentos. 1999. 113 f. Dissertação (Mestrado em Quimica)-Universidade Federal do Rio de Janeiro, Rio de Janeiro, 1999.

BUFFO, R. A.; REINECCIUS, G. A.; OEHLERT, G. W. Factors affecting the emulsifying and rheological properties of gum acacia in beverages emulsions. Food Hydrocolloids, v. 15, p. 53-66, 2001. http://dx.doi.org/10.1016/S0268-005X(00)00050-3

CAPPI, A.; DE JESUS, S. S.; MACIEL FILHO, R. Secagem de $\alpha$-amilase em spray dryer. In: CONGRESSO INTERNO DE INICIAÇÃO CIENTIFICA DA UNICAMP, 9., 2001, Campinas. Anais... Campinas: Unicamp, 2001.

CHANG, Y. I.; SCIRE, J.; JACOBS, B. Effect of particle size and microstructure properties on encapsulated orange oil. In: RISCH, S. J.; REINECCIUS,G. A. Flavor Encapsulation. Washington: American Chemical Society, 1988. p. 87-102. cap. 10. (ACS Symposium Series 370).

CHATTOPADHYAYA, S.; SINGHAL, R. S.; KULKARN, P. R. Oxidized starch as gum Arabic substitute for encapsulation of flavours. Carbohydrate Polymers, v. 37, p. 144-144,1998. http://dx.doi. org/10.1016/S0144-8617(98)00054-X

DE PAULA, R. C. M.; RODRIGUES, J. F. Composition and rheological properties of cashew tree gum, the exudates polysaccharide from Anacardium occidentale L. Carbohydrate Polymers, v. 26, p. 177-181,1995. http://dx.doi.org/10.1016/0144-8617(95)00006-S

DE JESUS, S. S. Desenvolvimento e analise do processo de secagem de [alfa]-amilase por microondas a vácuo. 2002. $161 \mathrm{f}$. Dissertação 
(Mestrado em Engenharia Quimica)-Universidade Estadual de Campinas, Campinas, 2002.

DZIEZAK, J. D. A focus on gums. Building in texture, stability, and emulsification are just some of ways in which gums aid product development: Special Report. Food Technology, v. 45, n. 3, p. 116-132,1991.

FILKOVÁ, I.; MUJUMDAR, A. S. Industrial Spray Drying systems in Handbook of Industrial drying. New York: Marcel Dekker Inc., 1995. $742 \mathrm{p}$.

GOUBET, I.; QUERE, J. L.; VOILLEY, A. J. Retention of aroma compounds by carbohydrates: Influence of their physicochemical characteristics and of their physical state. A review. Journal Agricultural of Food Chemistry, v. 46, p. 1981-1990, 1998. http:// dx.doi.org/10.1021/jf970709y

INHAMUNS, A. J.; FRANCO, M. R. B. EPA and DHA quantification in two species of freshwater fish from Central Amazonia. Food Chemistry, v. 107, p. 587-591, 2008. http://dx.doi.org/10.1016/j. foodchem.2007.07.032

KRABBENDAM, L. et al. Relationship between DHA status at birth and child problem behaviour at 7 years of age. Prostaglandins, Leukotrienes and Essential Fatty Acids, v. 76, p. 29-34, 2007. PMid:17074476. http://dx.doi.org/10.1016/j.plefa.2006.09.004

LAMPRECHT, A.; SCHÄFER, U.; LEHR, C. M. Influences of process parameters on preparation of microparticle used as a carrier system for $\Omega-3$ unsaturated fatty acid ethyl esters used in supplementary nutrition. Journal of Microencapsulation, v. 18, p. 347-357, 2001. PMid:11308225. http://dx.doi.org/10.1080/02652040010000433

LEITE, J. T. C. Obtenção de extrato de inulina de Chicória (Cichorium intybus) por abaixamento de temperatura e secagem por spray dryer. 2001. 120 f. Dissertação (Mestrado em Engenharia Agrícola)-Universidade Estadual de Campinas, Campinas, 2001.

MARTIN, C. A. et al. Ácidos graxos poliinsaturados ômega-3 e ômega-6: importância e ocorrência em alimentos. Revista de Nutrição, v. 19, n. 6, p. 761-770, 2006.

NARAYAN, B.; MIYASHITA, K.; HOSAKAWA, M. Physiological effects of eicosapentaenoic acid (EPA) and docosahexaenoic acid (DHA) - A review. Food Reviews International, v. 22, n. 3, p. 291-307, 2006. http://dx.doi.org/10.1080/87559120600694622

NORI, M. A. Ingredientes e aditivos microencapsulados na indústria de alimentos. Engenharia de Alimentos, v. 1, n. 6, p. 33-34,1996.

PAULETTI, M. S., AMESTOY, P. Butter microencapsulation as affected by composition of wall material and fat. Journal of Food Science, v. 64, p. 279-282, 1999. http://dx.doi.org/10.1111/j.1365-2621.1999. tb15882.x

RÉ, M. I. Microencapsulation by spray drying. Drying Technology, v. 16, n. 6, p. 1195-1236, 1998. http://dx.doi. org/10.1080/07373939808917460

RÉ, M. I. Microencapsulação: em busca de produtos "inteligentes". Ciência Hoje, v. 27, n. 162, p. 24-29, 2000.

ROBBERS, J. E.; SPEEDIE, M. K.; TYLER, V. E. Farmacognosia e Farmacobiotecnologia. Tradução de Benedetti, I. C. Supervisão Científica de Bastos, J. K. e outros. 1a ed., Editorial Premier. São Paulo. 1997. 372 p.

RODRIGUES, R. A. F. Preparo, caracterização e avaliação funcional de microcápsulas obtidas por spray drying, contendo extrato de café crioconcentrado. 2004. 239 f. Tese (Doutorado em Engenharia de Alimentos)-Universidade Estadual de Campinas, Campinas, 2004.

SEATON, T. The Omega 3 Explosion. Nutraceuticals World Magazine, 2006.

SHAHIDI, F.; WANASUNDARA, U. N. Omega 3-fatty acids: nutritional aspects and production technologies. Trends Food Science Technology, v. 9, p. 230-240, 1998. PMid:21299575. http:// dx.doi.org/10.1016/S0924-2244(98)00044-2

SHAHIDI, F.; HAN, X. Encapsulation of food ingredients. Critical Review in Food Science and Nutrition, Boca Raton, v. 33, n. 6, p. 501-47, 1993. PMid:8216812. http://dx.doi. org/10.1080/10408399309527645

SIMOPOULOS, A. P. Omega-3 fatty acids in wild plants, nuts and seeds. Asia Pacific Journal of Clinical Nutrition, v. 11, n. 6, p. 163-73, 2002. http://dx.doi.org/10.1046/j.1440-6047.11.s.6.5.x

UAUY, R.; VALENZUELA, A. Marine oils: the health benefits of $n-3$ fatty acids. Nutrition, v. 6, n. 7-8, p. 680-684, 2000. http://dx.doi. org/10.1016/S0899-9007(00)00326-9

WAREING, M. V. Exudate gums. In: IMESON, A. Thickening and gelling agents for food. 2 th ed. London: Blackie Academic \& Professional, Chapman \& Hall, 1997. p. 87-118.

WENDEL, S.; ÇELIK, M. Uma visão geral sobre o uso da tecnologia de Spray-Drying. Pharmaceutical Technology, p. 31-45, 1998.

ZAKARIA, M. B.; RAHMAN, Z. A. Rheological properties of cashew gum. Carbohydrate Polymers, v. 29, n. 1, p. 25-27, 1996. http:// dx.doi.org/10.1016/0144-8617(95)00132-8 